\title{
The Syntax of Personal Pronouns in the Bima Language
}

\author{
Arafiq $^{1}$ \\ ${ }^{1}$ English Department, Mataram University, Mataram, Lombok, Indonesia \\ Correspondence: Arafiq, English Department, Mataram University, Mataram, Lombok, Indonesia. E-mail: arafiq \\ @unram.ac.id
}

Received: May 20, 2020; Accepted: June 1, 2020; Published: June 1, 2020

\begin{abstract}
This article aims at describing the syntactic properties and distributions of Personal Pronouns in the Bima Language, a language spoken by approximately 9000 people who inhabit the eastern part of Sumbawa Island. This number of speakers does not include those who live in Reo Pota Manggarai, East Nusa Tenggara. The Bima Language is grouped into Sumba-Bima Subgroup of Central Malayo-Polynesian (CMP) branch of Austronesian Language. Data in this study are the linguistic units from morphems level to clausal level. The data were taken from conversations and monologues recorded in the real situations in which the Bima Language is used. The focus of this paper is to describe the personal pronoun system of the Bima Language, describing types of personal pronouns and their syntactic properties and distributions. Based on the analysis, the Bima Language has a set of morphologically independent personal pronouns (full pronouns) and a set of clitics. Both sets of personal pronouns show the same syntactic properties and distributions. These two sets of personal pronouns are able to occur as independent clausal arguments of both intransitive and transitive constructions. In addition to their distributions, these two sets of personal pronouns can occur with numerals, relatives, and NPs. However, only full personal pronouns can combine with demonstratives.
\end{abstract}

Keywords: personal pronoun, clitics, syntactic distribution, the Bima Language

\section{Introduction}

The Bima Language is grouped in the Bima-Sumba-Flores Subgroup by Blust (2008). However, this grouping is rather based on geographical consideration than anything other (Donohue \& Grime, 2008). The Bima Language is spoken by approximately 9000 speakers inhabit the eastern part of Sumbawa Island. The research documentation in the Bima Language has increased dramatically these days. With the speakers who are still significant in numbers, the preservation of the language in form of documentation is crucially important. The investigation has attracted a lot of attention of scholars, especially linguists who focus on the grammar analysis. The studies by Owen (2000) and Wouk and Arafiq (2016) are the latest done on the language aiming at analyzing the grammar. These two studies made great contributions to a clear description of The Bima Language grammar, particularly the Bima Language syntax.

Personal pronouns in the Bima Language have never been specifically studied. They are only understood as language entities labeled as subjects or objects in some studies. For instance, personal pronouns in the Bima Language must be cross-referencing with the clitics in phrasal level and the clitics can represent the personal pronouns. Another issue regarding the personal pronouns in the Bima Language is the fact that the distribution of the pronominal clitics vary within the clauses (Arafiq, 2005). These facts shows that personal pronouns in the Bima Language is quite complex. In this case, Dixon (2017) argues that pronouns should be described in terms of facts and principles of their functional uses due to the grammatical behaviors of pronouns is not entirely determined by their syntactic relations but also by other factors. Meanwhile, regarding to the distributions of pronouns, Baggaley (1998) stated that the exploration of syntactic category or pronouns should consider not only the possibility that pronouns are nouns, but that they may belong to other grammatical categories which make up noun phrases. This view is based on the assumption that even the simplest noun phrases have a complex internal structure and contain more than just one.

The pronouns in the Bima Language, might set a new light into theories on Pronouns (Baggaley 1998) and Dixon (2010 \& 2017) which suggest that subjective and objective full pronouns are dominant in human languages while clitics are not. In more specific issue about Personal Pronouns, Balukh (2015) stated that personal pronouns can be morphologically independent and bound forms. This study will examine if the case in the Bima Language 
contributing the fact that clitic pronouns have unique syntactical properties, distribution, and functions worthy of revisiting the current views of personal pronouns.

Pronouns are words used to refer other nouns (Alwi, Dardjowodjodjo, Lapoliwa, \& Moeliono, 2008: 249). In other words, they are used to replace people and things because their function is to replace the nouns (see also Chaer, 1998: 91). In fact, pronouns can serve syntactic subject, object, and also predicate. Further (Alwi, et.al. 2008) sated that another characteristics of pronouns are closely related to their references which are flexible depending on who speaks to whom or who speaks what and categorized pronouns into (1) personal pronouns, (2) possessive pronouns, (3) demonstrative pronouns, (4) interrogative pronouns, (5) relative pronouns, and (6) indefinite pronouns.

Pronouns are language units to replace the full noun phrases. Therefore, they take syntactic positions similar to what the noun phrases do (Baggaley, 1998:1). Baggaley (1998) believed that pronouns should be projected as Determiner Phrases (DPs). However, this approach still remains a debate among linguists, especially at the word level. Abney (1987) and Ritter (1991) proposed that pronouns are categorized into Determiners (Ds) and Numerals (Nums), so that they belong to functors. Meanwhile Noguchi (1997) and Zwarts (1994) argued that they are Nouns (Ns), and they belong to lexical items. In line with the later claim, Dixon (2017) stated that pronouns behave more like complete Noun Phrases (NPs) which can fill an argument slot in the phrases.

\subsection{The Properties of Personal Pronouns}

With regard to their forms, personal pronouns in all languages exhibit alternations. Personal pronouns may realize into full pronouns, reduced pronoun, or clitic pronouns and even in form of dependent affixes. In this case, the language like Rote Ndao can be a good example of this phenomenon. In Rote Ndao, all personal pronouns can have their reduced forms, clitics, and affixes, accept the second singular which does not have its reduced forms (Balukh, 2015). Unlikely, the Sambori language is lack of the paradigm where personal pronouns only have full forms and clitics, without having reduced pronouns and affixes (Arafiq, Hanafi, Mu'adz, \& Yusra, 2018). The following Table 1 shows the personal pronouns paradigm in Rote Ndao and Sambori Language.

Table 1. Personal Pronouns Paradigms in Rote Ndao and Sambori Language

\begin{tabular}{|c|c|c|c|c|c|c|c|c|}
\hline & & Pron & Full & Reduced & Clitics & & Affixes & \\
\hline & & & & & Pre & Enc & Pref & Suf \\
\hline \multirow[t]{3}{*}{$\mathbf{R N}$} & First & $1 \mathrm{SG}$ & $j a^{\prime} a$ & $\mathrm{Ja}$ & $K u$ & - & $k U-$ & $-k u$ \\
\hline & & 1PL-ex & $j i{ }^{\prime} i$ & $J i$ & (nga) 3 & - & $n g A 4-$ & $-' a$ \\
\hline & & 1PL-in & $E d h i$ & (ti) & $T i$ & - & $t A-$ & $-t i$ \\
\hline \multirow[t]{3}{*}{ SL } & First & $1 \mathrm{SG}$ & Rae & - & $k a-$ & $-n g g u$ & - & - \\
\hline & & 1PL-ex & ame(re) & - & $m a-$ & $-m a$ & - & - \\
\hline & & 1PL-in & Inta & - & ta- & $-t a$ & - & - \\
\hline \multirow[t]{2}{*}{$\mathbf{R N}$} & Second & $2 \mathrm{SG}$ & $E u$ & - & $M u$ & - & $m U-$ & $-m u$ \\
\hline & & $2 \mathrm{PL}$ & Miu & (mi) & $M i$ & - & $m I-$ & $-m i$ \\
\hline \multirow[t]{2}{*}{ SL } & Second & $2 \mathrm{SG}$ & $\mathrm{Oe}$ & - & $M a-$ & $-m a$ & - & - \\
\hline & & 2PL-hon & Eme & - & $T a-$ & $-t a$ & - & - \\
\hline \multirow[t]{2}{*}{$\mathbf{R N}$} & Third & $3 S G$ & Nenggu & $N u$ & na/ne & - & $n A-$ & $-' e$ \\
\hline & & $3 P L$ & Renggu & $R u$ & $R a$ & - & $r A-$ & $-s i$ \\
\hline \multirow[t]{2}{*}{ SL } & Third & $3 S G$ & ree & - & $n a-$ & $-n a$ & - & - \\
\hline & & $3 P L$ & re er $(a)$ & - & $n a-$ & $-n a$ & - & - \\
\hline
\end{tabular}

\subsection{The Distributions of Personal Pronouns}

It is widely claimed that the distributions of pronouns and their positions in morphosyntactical context and setting. Based on this approach, the distributions of pronouns are their co-occurrences with other categories. In Japanese, pronouns are to co-occur with the plural nouns and adjective freely in all three persons. Difference from the ones of English, Hebrew, and Dutch (Baggaley, 1998: 53-55).

(1) a. Watasi-tati gengogakusya

$$
1 \mathrm{pl} \quad \text { linguist }
$$

'We are linguists'

\section{b. Anata-tati ronrigakusya}


2pl logician

'You are logicians'

c. Kare-ra tetugakusya

$3 \mathrm{mpl} \quad$ philoshoper

'They are philosopher'

(2) a. Tissai kare

small $3 \mathrm{sg}$

'small he'

b. Sinsetuna anata

kind $\quad 2$ sg

'kind you'

Based on the above examples, (1)a, (1)b, and (1)c, it is suggested that Japanese has single class of pronouns, which includes first, second, and third person pronouns. Meanwhile, (2)a \& (2)b show that Japanese pronouns can actively co-occurrence with adjectives.

\section{Method}

The data used in this study were mainly taken from conversations and monologues in real situations in which the Bima Language is used. These data were transcribed firstly before elicited. In addition, as the writer is the speaker of the Bima Language, some data came from the writer's repertoires of the language. Some data from the prior researchers were also presented to support particular issues in this study. These data were analyzed qualitatively by using distributional methods, utilizing the language parts as the instrument of analysis which was done by omitting, replacing, advancing, inserting, repositioning, reformatting, and reduplicating the language units (Sudaryanto, 1993 \& Mahsun, 2015).

\section{Results and Discussions}

\subsection{Personal Pronouns Paradigm in The Bima Language}

The Bima Language has two sets of personal pronouns. The first set of personal pronouns is full pronouns which are morphologically independent. Meanwhile, the second set of personal pronouns is identified as clitics which are morphologically bound. Full personal pronouns appear to exhibit in one to two words, while clitic personal pronouns exhibit in one syllabic morphemes which occur before the predicates (preclitic) and after the predicates (enclitic). The former seems in line with the Rote Ndao, but the later does not because clitics in Rote Ndao tend to be independent (Balukh, 2015). The paradigm of personal pronouns of the Bima Language is shown in Table 2.

Table 2. The Bima Language Personal Pronoun Paradigms

\begin{tabular}{lllll}
\hline \multirow{5}{*}{ First } & Pron. & Full & Clitics & \\
\cline { 2 - 5 } & & & Preclitic & Enclitic \\
\cline { 2 - 5 } & 1SG & Nahu & $k u-/ k a-$ & $-k u /-k a$ \\
\cline { 2 - 5 } & 1SG-hon & Mada & $k u-/ k a-$ & $-k u /-k a$ \\
\cline { 2 - 5 } & 1PL-hon & Mada doho & $m u-/ m a-$ & $-m u /-m a$ \\
\cline { 2 - 5 } & 1PL-ex & Nami & $m u-/ m a-$ & $-m u /-m a$ \\
\hline \multirow{5}{*}{ Second } & Ndai & ta- & $-t a$ \\
\cline { 2 - 5 } & 2SG & Nggomi & $m u-/ m a$ & $-m u / m a$ \\
\cline { 2 - 5 } & 2SG-hon & Ita & ta-/ta & $-t a / t a$ \\
\cline { 2 - 5 } Third & 2PL-hon & Ita doho & ta-/ta & - -ta/ta \\
\cline { 2 - 5 } & 3SG & Sia & $n a-$ & $-n a$ \\
\hline & 3PL & Sia doho & $n a-$ & $-n a$ \\
\hline
\end{tabular}

It can be seen in the above table that the personal pronouns are categorized into person and number. The Bima personal pronouns have first, second, and third number. The plural form of the first person is involved with exclusive and inclusive. Honorific is also distinguished in the first and the second, but not in the third. Gender in 
the Bima Language is absent. Generally, clitic pronouns and full pronouns do not show any similarities in forms. However, the 2SG-hon and 2PL-hon clitic pronouns seem to reflect the form of the full pronouns. This suggests that the historical relations between full pronouns and clitics are restricted to certain pronouns.

\subsection{The Distributions of Personal Pronouns in The Bima Language}

Personal pronouns in the Bima Language can take the slot of full Noun Phrases (NPs) as clausal arguments, which functions either as subject (S) or object $(\mathrm{O})$, or as the complement of preposition. The next section is devoted to the description of full personal pronouns and their distribution in argument position.

\subsubsection{Full Pronoun as Subject of Intransitive Predicates}

Intransitive constructions are constructions which only require one core argument (+ term). In the Bima Language, the slot of core argument can be taken by both verbal and non-verbal predicates. Having such predicates, pheripheral arguments (-term) are marked, for example with preposition. Consequently, the semantic roles that the subject argument of intransitive predicates may have, are different from one argument to another, depending on the meaning or semantic properties of the verbs in the constructions. The pronoun as subject may have a semantic role of agent as shown in example (3) or (4) or patient as in (5). In (3) a pheripheral argument is marked with preposition $a k a$ ' $\mathrm{LOC}$ ', which is optional in the clause.

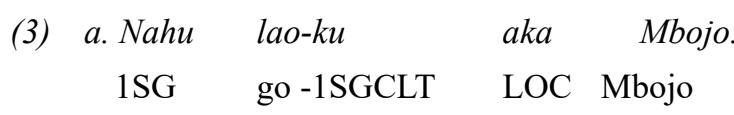

'I went to Mbojo'

b. Aka Mbojo nahulao-ku.

LOC Mbojo 1SG go-1SGCLT

'I went to Mbojo'

(4) a. Bala ai sanai, name tu'u-mu.

Day time after, 1EX/Pl start-2EXCLT/Pl

'The day after, we started'

$\begin{array}{llll}\text { b. Nami } & \text { tu' }^{\prime}-m u & \text { bala ai } & \text { sanai. } \\ 1 \mathrm{EX} / \mathrm{Pl} & \text { start-2EXCLT/Pl } & \text { day time } & \text { after, }\end{array}$

'The day after, we started'

(5) Sia wa'ura made.
$3 \mathrm{~S}$ already die
'He/she died already'

The subject argument in the Bima Language tends to be so flexible for it can take pre-verbal position or post-verbal position. In example (6), the verb made 'die' is intransitive verb, which syntactically needs a single patient core argument which is mada labeled as $1 \mathrm{SGHON}$. This argument is semantically the same person with the clitic argument $K u$ labeled as 1SGCLT in the clause. This evidence suggests that the Bima Language operates the split alignment properties of the verbs. As Dixon (2010:140) stated that a language which belongs to split alignment, is the one whose intransitive subject argument acts as a transitive object argument in terms of syntactic position.

\section{(6) $\mathrm{Ku}$ - made-ra mada ina -e \\ 1SGCLT- die -PERF 1SGHON mother - INTEN}

'I would be in trouble, mother' (I die, mother)

As already stated above, the predicates in the Bima Language can be taken by non-verbal categories like nouns, adjectives, adverb, numeral, or prepositions. These categories exhibit various syntactical unit may refer to as attributes, location, and existence. . In this case, Pyne (1997) stated that this phenomenon is common for some the languages in the world, especially the language whose argument can be expressed in the forms of bound forms. The subject argument of intransitive non-verbal predicates does not have a fixed position in sentences. It can come before or after the predicate. Example (7), (8), and (9) below show that the predicates of non-verbal sentences occur with a full pronoun as subject argument.
(7) a. Sia
$[\text { dou Dompu }]_{N P}$
$3 \mathrm{SG}$
[people Dompu] 
'He is Dompunese'

b. [Dou Dompu $]_{\mathrm{NP}} \mathrm{Sia}$

[People Dompu] 3SG

'He is Dompunese'

(8) a. Sia [ta sabae ele $]_{P P}$

3SG [LOC side south]

'She/he is at the south side'

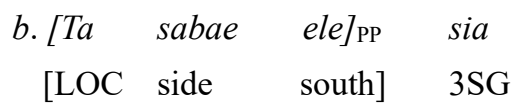

'She/he is at the south side'

(9) a. Sia [na'e $]_{\text {Adj }}$

3SG [big]

'She/he is big'

b. $[\mathrm{Na} \text { 'e }]_{\mathrm{Adj}} \mathrm{Sia}$

[Big] $\quad 3 \mathrm{SG}$

'She/he is big'

3.2.2 Full Pronoun as Argument Transitive Predicates

In the Bima Language, transitive constructions can have one or more verbs in a clause. Like intransitive, the arguments of transitive verbs do not take a definite position. Both argument subject and object can take pre-verbal or post-verbal positions interchangingly. Let's consider the following examples.

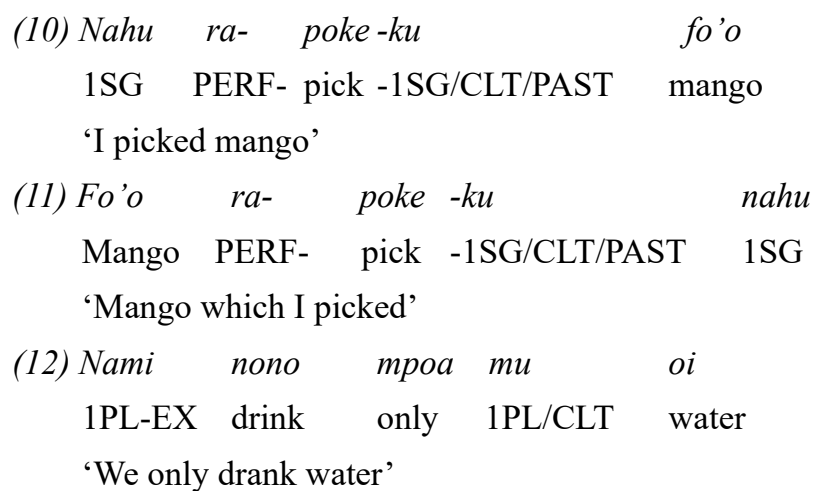
(13) $\mathrm{Oi}$ nono mpoa mu
Water drink only 1PL/CLT 1PL-EX
'Water which we drunk'

\subsubsection{Clitic Pronouns}

Like full pronouns, clitic pronouns in the Bima Language also do not have fixed position in clauses, both in intransitives, and in transitives. Clitic pronouns also mark the aspects or tenses of sentences with their positions in a sentence. In intransitive constructions, the clititcs of argument subject take the pre-verbal position indicating that the construction has a futurative aspect/tense. However, when it takes the post-verbal position, the clitic shows resultative aspect/past tense. The following examples illustrate this phenomenon.

(14) $\mathrm{Ku} \quad$ lao

$1 \mathrm{SG}$ go

'I will go'

(15) Lao ku

Go $1 \mathrm{SG}$ 
'I went'

(16) $\mathrm{Ku}$ - poke fo'o

1SG- pick mango

'I will pick mangoes'

(17) Poke-ku fo'o

Pick-1SG mango

'I picked mangoes'

(18) $\mathrm{Mu}$ nono mpoa oi

2SG drink only water

'You will drink water only'

(19) Nono mpoa mu oi

Drink only 2SG INT water

'You drank water only

\subsubsection{Pronoun and other Constituents}

This subsection describes the distributions of pronouns in the constructions with other constituents in a clause. The constituents which are seen are demonstratives, numerals/quantifiers, relative clauses, and Noun Phrases (NPs).

\section{Pronouns with Demonstratives}

Like full noun phrases (NPs), full pronouns in the Bima Language can be folowed by demonstratives as modifiers. The use of these demonstratives is to evaluate and appraise one. The demonstratives follow the full pronouns which functions as subject and object. All personal pronouns can take modifiers whatever the number they exhibit. All types of full pronouns with their plural counterparts can go with demonstratives. Third person singular Sia 'she/he' and its plural counterpart Sia doho 'they', First person singular Nahu 'I' and its plural counterparts Nami 'we', Nggomi 'you' and its plural counterpart Nggomi doho 'you' can go well with demonstratives ede, 'that' and ake 'this' as seen in the followings.

$\begin{array}{rllllll}\text { (20) Sia } & \text { ede } & \text { wati } & \text { loa } & -n a & \text { nefa taho ndai } & \text { ntoina } \\ \text { 3SG } & \text { Det } & \text { NEG } & \text { able } & -3 \mathrm{SG} / \mathrm{CLT} \text { forget good 1Ink } & \text { past }\end{array}$

'She cannot forget our generousity in the past'

(21) Siadoho ede wati loa na nefa taho ndai ntoina

3PL Det NEG able 3SG/CLT forget good 1Ink past

'They cannot forget our generousity in the past'

(22) Nahu ake ana dou ma da- wara

1SG Det child person RE NEG- rich

'I am a poor person'

(23) Namiake ana dou ma da- wara

1Eks Det child person REL NEG- rich

'We are poor persons'

(24) Nggomi ede ari nahu

2SG Det young sibling $1 \mathrm{SG}$

'You are my young brother'

(25) Nggomi doho ede ari nahu

2PL Det young sibling 1SG

'You are my young brothers'

The distribution of clitics in the Bima Language is different from full pronouns. Clitics cannot be followed by demonstrative as modifiers. Example (26a) shows that the full pronoun Sia ' $3 \mathrm{SG}$ ' is followed by demonstrative 
ede. When clitic na ' $3 \mathrm{SG}$ ' is used to substitute the full pronoun Sia ' $3 \mathrm{SG}$ ' as shown in (26b), the sentence is not ecceptable in the grammar of the Bima Language. The sentence is ecceptable only if the clitic $n a$ ' $3 \mathrm{SG}^{\prime}$ ' is not modified as shown in (26c).

(26) a. Sia ede wati

3SG Det NEG able 3SG/CLT forget good 1PL-Ink past

'She/he cannot forget our good conduct in the past'

$\begin{array}{llllllll}\text { b. }{ }^{*} \mathrm{Na} & \text { ede } & \text { wati loa } & \text { na } & \text { nefa taho } & \text { ndai } & \text { ntoina } \\ \text { 3SG/CLT } & \text { Det } & \text { NEG able } 3 \mathrm{SG} / \mathrm{CLT} \text { forget good } & \text { 1PL-Ink past } \\ \text { c. } \mathrm{Na} & \text { loa } & \text { nefa } & \text { taho ndai ntoina } & & \\ 3 \mathrm{SG} / \mathrm{CLT} & \text { able } & \text { forget } & \text { good } & \text { 1PL-Ink past } & & \end{array}$

Pronouns with Numerals/Quantifiers

Pronouns in the Bima Language can co-occur with numerals and quantifiers without regarding their number. In other words, both plural and singular pronouns can take numerals. The first plural pronoun Nami doho 'we' takes numeral dua 'two' as its modifier in (27). The first singular Nahu 'I' and sia 'she/he' each take numeral kese 'the one' as their modifier in (28) and (29).
(27) Nami doho
dua mu lao awa lombo
1PL-Eks
two 1-CLT go prep
Lombok

'Two of us will go to Lombok ' (Lit: We, two are going to go to Lombok')
(28) Nahukese
mpa ma da- ntau piti
$1 \mathrm{SG}$ alone
only REL NEG- have money

'I am, the only one who does not have money'
(29) Sia kese ede na lao awa lombo
3SG alone Det 3CLT go Prep Lombok

'She/he is alone who is going to go to Lombok'

\section{Pronouns with Relative Clauses}

In the Bima Language, only full noun phrases (NPs) can be followed by relative clauses. The relative clauses are marked with $m a$ 'REL'. However, this relative marker needs further and deeper analysis regarding its syntactic property that signs both relative and progressive. As a relative, $m a$ in (30) follows the full pronoun 2SG 'Nggomi' and with the verbal clause. However, as a progressive marker of a verb, $m a$ does not require any verbal clause to construct a good sentence as shown in (31).
(30) Nggomi
[ma kani
baju monca] mai
ja
pu ta ake.
2SG
[REL wear shirt yellow] come SOFT
SOFT prephere.
'You who are wearing the yellow shirt, come here, please?'

\section{(31) Nggomi [ma kani baju monca] \\ 2SG [Prog wear shirt yellow]}

'You are wearing a yellow shirt'

\section{Pronouns with NPS}

The occurrence of personal pronouns with the NPs is governed by discourse situation. This situation suggests the speakers to employ the construction to ovoid the contextual ambiguity considering that only the speakers themselves who are able to identify the referents. All types of personal pronoun (full personal pronouns) behave similarly regarding to their occurrences with NPs. La Duru in (32) and (33) requires an NP to precede or to follow it as a topic of the construction. Similarly, the second plural pronoun sia doho and the first plural pronoun ndai require dou siwe aka labo dou mone aka 'Those girls and those boys' as shown in (34) and (35) and dou mone 'The male' as shown in (36) and (37) below.
(32) [Laduru] sia wati loa -na lao ese tio abu-na
[La duru] 3SG NEG able -3SG go LOC see abu-3POS 
'La Duru, he cannot go to see his father'

(33) Sia [La Duru] wati loa -na lao ese tio abu-na

3SG [La duru] NEG able -3SG go LOC see abu-3POS

'He, La Duru, he cannot go to see his father'

(34) [Dou siwe aka labo dou mone aka] siadoho wunga nuntu -na.

[Person female Det with people male Det] 3PL PROG speak -3PL/CLT

'The female person and the male person, they are talking'

(35) Sia doho [dou siwe aka labo dou mone aka] wunga nuntu -na.

3PL [Person female Det with person male Det] PROG speak -3PL/CLT

'They, the female person and the male person are talking'

(36) Ndai [doumone] na- hari $-k a i-k u$ ba dou wati si Loa ta kanggihi.

1PL-ink [person male] 3SG- laugh -CAUS-INT AGT other NEG COND able 1PL-ink/CLT farming

'We, as male will be laughed by others if we cannot do farming'

(37) [Dou mone] ndai na-hari $-k a i \quad-k u$ ba dou wati si loa ta kanggihi

[person male] 1PL-ink 3SG-laugh -CAUS -INT AGT other NEG COND able 1PL-ink/CLT farming

'As male, we will be laughed by others if we cannot do farming'

Dixon (2017) also found out that personal pronouns in English can occur with specific nouns both as the subjects and objects. However, this occurrence is encountered less frequently with the singulars.

\section{Conclusions and Suggestions}

\subsection{Conclussions}

Personal pronouns in the Bima Language are realized into two forms, namely full pronouns and clitic pronouns. Both full pronouns and clitic pronouns can stand in any position in sentences, both as argument subject and object. Clitic pronouns cannot occur as an independent NP argument. The clitic pronouns can only serve as cross-references of the full NPs. However, in discourses, clitic pronouns can occur as an independent NP argument where the referent has been introduced before in a discourse, or mentally is understood. Only pronouns can co-occur with demonstratives, numerals/quantifiers, relative clauses, and other NPs but not the clitics.

\subsection{Suggestions}

Personal pronouns in the Bima Language are quite unique that viewing them with the syntactical point of views is not adequate. Other aspects of linguistics should be involved in order to get a comprehensive understanding on Personal Pronouns in the Bima Language in the future study.

\section{Acknowledgments}

I would like to thank to Prof. Ze Firdaus and Dr. Kamaluddin Yusra their valuable comments and suggestions to the writing of this manuscript. Thousands thanks should go to Dae Bu Bunyamin and friends who provided their important time in helping the recording of the data in this study. My thanks also go Rahmatullah who facillitated in the payment of the publication of the manuscript.

\section{References}

Abney, S. P. (1987). The English Noun in Its Sentential Aspect. Doctoral dissertation, MIT, Cambridge, Massachusetts.

Alwi, Hasan., Dardjowodjodjo, S., Lapoliwa, H., \& Moeliono, A. (1998). Tata Bahasa Baku Bahasa Indonesia Edisi Ketiga. Jakarta: Balai Pustaka.

Arafiq (2005). Konstruksi Kausatif dan Aplikatif dalam Bahasa Bima. A Master Thesis. Universitas Udayana . Denpasar, Bali.

Arafiq, Hanafi, N., Mua'dz, H., \& Yusra, K. (2018). The Syntactic Properties and Distributions of Personal Pronouns in Sambori Language. Kajian Linguistik dan Sastra (1-10): Muhammadiyah University Press.

Baggaley, V. (1998). The Syntactic Category of Pronouns. A Master Degree Thesis. Department of Linguistics. Calgary, Alberta: The University of Calgary. 
Balukh, J. E. (2015). Personal Pronouns of Dhao in Eastern Indonesia. Linguistik Indonesia, 33(2), 101-120.

Blust, R. (2008). Is There a Bima-Sumba Subgroup? Oceanic Linguistics, 47(1), 45-113. https://doi.org/10.1353/ol.0.0006

Chaer, A. (1998). Tata Bahasa Praktis Bahasa Indonesia, Jakarta: Rineka Cipta.

Dixon, R. W. M. (2010). Basic Linguistic Theory: Grammatical topics (Vol. 2). Oxford, New York: Oxford University Press. Retrieved from http://site.ebray.com/id/10674477.

Dixon, R. W. M. (2017). The Grammar of English Pronouns. Lingua, 33-44. Crorrmark. https://doi.org/10.1016/j.lingua.2017.08.002

Donohue, M., \& Grimes, M. C. (2008). Yet more on the position of the languages of Eastern Indonesia and East Timor. Oceanic Linguistics, 47, 114-158. https://doi.org/10.1353/ol.0.0008

Mahsun (2005). Metode Penelitian Bahasa. Jakarta: PT Raja Grafindo Persada.

Noguchi, T. (1997). Two Types of Pronouns and Variable Binding. Language, 73, 770-797. https://doi.org/10.2307/417326

Owens, M. (2000). Agreement in Bimanese. A Doctoral Thesis. University of Canterbury

Pyne, T. E. (1997). Describing Morphosyntax: A Guide for field linguists. United Kingdom: Cambridge University Press. https://doi.org/10.1017/CBO9780511805066

Ritter, E. (1991). Two Functional Categories in Noun Phrases: evidence from Modern Hebrew. In Syntax and Semantics 25: Perspectives on Phrase structure, ed. Susan Rothstein, 37-62. Academic Press: New York. https://doi.org/10.1163/9789004373198_004

Sudaryanto (1993). Metode dan Aneka Teknik Analisis Bahasa. Yogyakarta: Duta Wacana University Press.

Wouk, F., \& Arafiq (2016). The Particle Kai in Bimanese. Oceanic Linguistics, 55(2), 319-349. University of Hawai'i Press. https://doi.org/10.1353/OL.2016.0016

Zwarts, J. (1994). Pronouns and N-to-D Movement. In OTS Yearbook 1993.ed. Martin Everaert, Bert Schouten and Wim Zonneveld, 93-112. Utrecht: Utrecht University.

\section{Copyrights}

Copyright for this article is retained by the author(s), with first publication rights granted to the journal.

This is an open-access article distributed under the terms and conditions of the Creative Commons Attribution license (http://creativecommons.org/licenses/by/4.0/). 